\title{
The Implementation of Multicultural Education in Senior High Schools in Medan
}

\author{
Anwar Soleh Purba' ${ }^{1}$, Elly Malihah² , Achmad Hufad ${ }^{3}$ \\ ${ }^{1}$ Postgraduate School, Universitas Pendidikan Indonesia, Bandung, Indonesia \\ ${ }^{2}$ Department of Sociology Education, Universitas Pendidikan Indonesia, Bandung, Indonesia \\ ${ }^{3}$ Departement of Nonformal Education, Universitas Pendidikan Indonesia, Bandung, Indonesia \\ anwarsolehpurba12@gmail.com
}

\begin{abstract}
Multicultural education is one of learning that provides understanding and tolerance attitudes towardsdiversity. This study has reviewed the multicultural education system which will be the basis for children about the importance of diversity, whether the diversity in races, ethnicity, culture, religion, gender, economic status, and so forth. As for the research method used in this research is a constructive paradigm with a case study approach through observation, interviews, and documentation in the Yayasan Perguruan Sultan Iskandar Muda (YPSIM) to collect the data. To strengthen the data, the researchers prioritized informants who has a role in management structures, teachers, students from various ethnicities and religions as well as communities around the Yayasam Perguruan Sultan Iskandar Muda, Medan. The results of the study indicates that the Yayasan Perguruan Sultan Iskandar Muda Foundation has implemented a multicultural education program that has made students become more understand about the meaning of diversity and more tolerant of diversity in religion and ethnicity in Medan.
\end{abstract}

Keywords : implementation; multicultural education; tolerance

\section{Introduction}

Addressing the diversity in Medan city is one of the main objectives in implementing a multicultural education program. Because through multicultural education can be one way or method to introduce the diversity in ethnicity, race, religion, gender, and so on to the community, especially the students as the next generation. This is based on education being an important factor in understanding the concepts of culture, competence, social identity, and intersection to deepen the anti-discrimination approach so that social justice is carried out (Rozas \& Garran, 2013). The application of multicultural education certainly has great hopes for creating future generations who understand the meaning of diversity. So that through multicultural education, a harmonious society will be created.

The policy carried out by one of the private educational institutions, namely Yayasan Perguruan Sultan Iskandar Muda (YPSIM) Medan with a multicultural education-based curriculum policy is one of the evidences. Awareness of the increasing number of deviations in the city of Medan is one of the real forms of the low education obtained by the people who come from different identities. So that in responding to this, certainly an education equalization program is needed. So that the state in this case must provide learning opportunities for everyone (Gophinatan, 2007). Moreover, the implementation of multicultural education has the aim of creating a society that understands diversity, whether the diversity caused by economic, ethnic, religious, racial, gender, and other factors have an impact on the creation of new conflicts in society.

This multicultural education at YPSIM serves as one of the learning methods of embedding values, norms, and most importantly, to strengthen tolerance for students. One of the plans implemented is embedding as early as possible the attitude of diversity towards students. Because introducing diversity will make students more communicative despite 
different races, ethnicities, and religions (Venkatraman, 2016). This introduction can certainly be through various methods that are considered feasible to be applied in the school environment.

The occurrence of various social phenomena related to diversity always provides an understanding to safeguard the cultural identity of a nation, especially for the people in Medan. Because in the literature, ethnicity is often assumed to be the cultural identity of a group within a country or nation (Grosfoguel, 2004). So that the symptoms associated with the identity of a group become very sensitive in causing the conflict if an action occurs that injures the culture of the community. It can even have an impact on anti-revolutionary attitudes and can have an impact on warfare and the destruction of the nation's generation (Kolas, 2015). Therefore, multicultural education applied by the Yayasan Perguruan Sultan Iskandar Muda is one of the concrete forms of how to provide understanding to the general public about being in diversity.

As stated by Camilleri (2016) that in order to deepen someone's knowledge, formal training still needed for teachers to provide teaching in a multicultural society, especially schools. To support the running of all multicultural learning plans, YPSIM also employs staffs and teachers who understand multicultural values and are more innovative in delivering the materials. To support teacher's knowledge, YPSIM has anticipated by often making training activities that are useful to increase the knowledge of the teachers in understanding the value of multiculturalism and how to implement it in learning programs. This training activity is often carried out in schools and outside schools by inviting competent speakers to understand the multicultural curriculum.

Through multicultural education, students will be introduced to various meanings of ethnic, cultural, and religious diversity. The introduction was carried out by YPSIM through two basic methods, by creating diversity recognition programs through school culture and class culture. Through school culture, YPSIM often adapt cultural festivals, and students from each ethnic group will display a culture that is unique to them. This kind of activity is certainly needed because every student needs more recognition from the community regarding ethnic diversity which is a form of local identity that makes them feel more secure and confident (Paul, 2017).

Based on information related to multicultural education programs and planning applied in one of the private educational institutions, namely Yayasan Perguruan Sultan Iskandar Mudan in Medan, the researchers did not only raise the extent to which this multicultural education program was successfully implemented, but also will explain the impact of multicultural education on students and communities around the city of Medan.

Researchers' interest in raising the planning of multicultural learning programs is also based on various social symptoms have been found related to social deviations caused by antitolerant attitudes towards identity diversity. The diversity in identity that the researcher intended included diversity in religion, ethnicity, culture, race, gender, and social class. These kind ofdiversity are often become the trigger for prolonged conflict, so they often cause losses both materially and socially.

\section{Theoretical Framework}

Previously, Banks (2011) in his research stated that multicultural education is a broad concept with several different and important dimensions. Therefore, multicultural education must be widely understood and not only as theoretical. This program must be implemented in a real and structured manner. Thus, the implementation process will be an action that has a real 
impact on the development of students. Education certainly becomes one of the main means in introducing values, norms, and knowledge to students. This includes the value of diversity that students must know. As Choirul's statement (2013) also states that education is an effort to grow and develop innate potential, both physically and spiritually, in accordance with the values that exist in society and culture.

Erlan Muliadi (2012) states that multicultural education in schools can be a land to eradicate prejudice, and, at the same time, to train and build students' character so that they are able to be democratic, humanist, and pluralist. In addition, Zainal Arifin (2012) said that through multicultural-religious education the attitude of respect for diversity with the concept of religious education emphasizes submission and obedience to all of Allah's commands.

Dede Rosyad (2014) states that through multicultural education in schools, the design of the learning process is needed, preparing curriculum and evaluation design, and preparing teachers who have multicultural perceptions, attitudes, and behaviors. Furthermore, Ibnu Ambarudin (2016) states that multicultural education is needed by the Indonesian people to reduce the occurrence of horizontal conflicts between communities, whether becauseof cultural, ethnicity, customs, or religion diversity. Likewise, Iis Arifudin (2007) stated that multicultural education is a process of cultivating values and ways of life respecting, sincere, and tolerant of the diversity of cultures that live in the midst of a pluralistic society.

\section{Methodology}

The research method used by the researchers is qualitative research with descriptive approach. According to Bogdan and Taylor, qualitative research is a research procedure that produces descriptive data in the form of written or oral words from people and observable behavior. Similarly, the Creswell (2014) stated,"Qualitative research is described comparatively for provide a theoretical and application basis with five approaches, which are narrative approaches, phenomenology, grounded theory, ethnography, and case studies." In this study, the researchers are more specific in using case study approach. Because through this approach, researchers were more easily explore the data relating to an implementation in the scope of the educational bureaucracy. This study also used data triangulation to look for comparisons with social issues related to the implementation of multicultural education in Medan.

The researcher collected data using a descriptive approach because the informants consisted of various group identities and consisted of several structures that had different social statuses. The data was collected through an interview process with students coming from several ethnic groups, religions, races, cultures, gender, and economic status. In addition, the researchers also collected qualitative data from several local governments, administrators of the college foundations, alumni, and the local community. Through this research, the researcher will be able to explain how the implementation of multicultural education in high school and will be written in the form of scientific work.

\section{Discussion}

The senior high school (SMA) in the Yayasan Perguruan Sultan Iskandar Muda in Medan is one of the educational institutions that applies the 2013 curriculum. As the 2013 curriculum 
in a structured high school curriculum develops a balance between spiritual, social, creativity, curiosity, cooperation, psychomotor, and intellectual. Therefore, YPSIM has the same vision in implementing a multicultural education program in order to create a harmonious society. The findings of researchers related to the implementation of multicultural education within the YPSIM in Medan can be explained as follows.

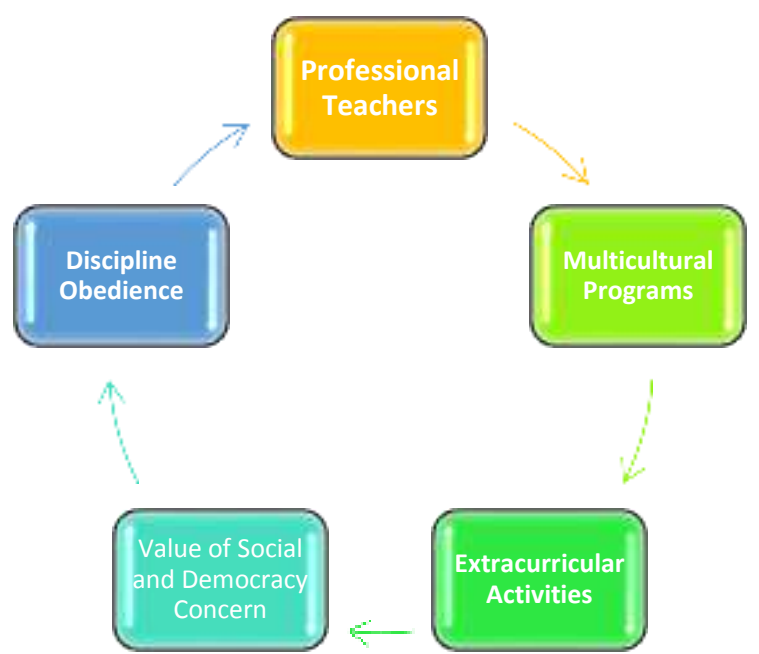

Figure 1.0 Basic Value of Multicultural Education Implementation at YPSIM

a. Providing Nation-Visioned Teachers

The availability of professional teachers is one of the most supportive aspects of the implementation of a diversity education program at the YPSIM. Because the teacher is one of the most important media in the learning process. So, in this case, YPSIM is very serious in selecting teachers who will become teachers in the schools, especially in senior high school (SMA).

b. Creating a Multicultural Education Learning Programs

The learning process aimed at creating a shared understanding in diversity certainly requires a mature learning plan. Thus, in this program, teachers are required to have multicultural value-based learning designs and certainly not far from the diversity values that are in accordance with the 2013 curriculum. Responding to this, the foundation has made a learning plan based on multicultural values.

c. Extracurricular Activities that Embed the Value of Diversity and Equality

To support the implementation of a diversity education program, YPSIM also provides extracurricular activities such as arts, organization, sports, and subject clubs in which there are values of diversity. These extracurricular activities are considered by the foundation as one of the creation of school culture which can also be a means of introducing multicultural values.

d. Teaches Social and Democracy Concern

There is a social service program submitted by YPSIM to be run by the Student Council as an organization in schools. This social service activity is useful as one of the programs in fostering the understanding of the students about the value of diversity or humanity. This social service activity can be in the form of giving assistance to an orphanage, students who cannot afford it, and the surrounding community who are not 
capable economically. These activities are also believed by the foundation to be one of learning for the students to be more concerned with the surrounding environment.

e. Practicing Obedience and Enforcement of Discipline

Practicing obedience is being implemented in order to keep being discipline and concern towards multicultural values at YPSIM. So, the foundation makes a regulation in which the regulation has been compiled based on guidelines for assessing students' attitudes or manners that are adjusted to the weight of violations of the foundation's rules. If students commit a violation such as hurting someone else's feelings or saying bad words then they are given a violation with a weight of 10 .

In addition, YPSIM is also made programs and policies previously written theoretically to implement them in learning activities. Among them are the basic concepts of the application of multicultural education in the foundation which are as follows.

Multicultural-Valued Vision and Mission

a. In addition to the value of diversity taught in the YPSIM in Medan, the educational foundation also has planning that continuously change in accordance with the demands of an increasingly developing education. However, the vision of YPSIM's school remains on its idealistic concept, "Educating the young generation of Indonesia to be intelligent, religious, humanistic human beings in the frame of equality and diversity."

b. Leadership and Management

The other way that YPSIM has done in training leadership and good relations among teachers is by preparing various programs which include periodic enrichment and training, regular evaluation, joint holiday and outbound.

c. Capacity and Culture

The implementation of multicultural value education that is formed from school culture and class culture at the YPSIM can be seen through several facilities that support the implementation of multicultural values, among which can be seen from several programs as follows,

1. School monuments that represent the foundation's vision,

2. Religious Education discussing universal values,

3. Celebration of Religious Holidays and Bhineka Tunggal Ika (Unity in Diversity),

4. Seating arrangements as a way of interacting and cultural exchange,

5. Praying activity according to each religion and belief before the lesson takes place and after the last lesson,

6. Providing worship facilities or pavilion at school.

d. Student Activities

Yayasan Perguruan Sultan Iskandar Muda also makes various activities that support talent and multicultural value understanding activities. These activities are always carried out outside the hours of classroom learning activities. It is expected that students will also understand the importance of diversity understanding at YPSIM. Among those activities are, Sports Club, Music Art, Science, Language, Diversity Radio, Student Node, Religious Activities: Pesantren Kilat, Retreats, and Seminars or Workshops.

e. Collabroration with Wider Community

The programs at YPSIM in multicultural education that collaborates the role of the outside community will certainly be very useful, such as involving families and communities. Through this cooperation, it is expected that changes will be formed that 
lead to better things. The collaboration is in the form of a chain crossed foster child program and cross subsidies and social assistance.

f. Curriculum and Teaching

Actually, since the foundation was established, they have implemented multicultural education-based learning in schools. However, it has not been included in the syllabus and lesson plan. However, with the seriousness in implementing multicultural education, YPSIM incorporates multicultural values in each learning.

Previously, the Yayasan Perguruan Sultan Iskandar Muda (YPSIM) which was established in 1987 had applied the concept of tolerance value. The implementation of multicultural education at YPSIM is inseparable from the goal of overcoming the problem of poverty and discrimination that harms marginal communities. The purpose of multicultural education applied by the YPSIM is certainly in line with the understanding presented by Piere Bourdieu who explained the concept of social production. Piera revealed that if there is a new generation from poor families, changing their social status to be better will be very difficult. It is because in taking education they will be very difficult, of course because education capital is expensive.

Yayasan PerguruanSultan Iskandar Muda has made ideas and actions by making houses of worship and pavilions in close proximity to the school. Theoretically, every educational institution certainly teaches multicultural values that exist in the community. However, its implementation in the form of action often does not arrive. So in this case, YPSIM acted realistically by building a place for prayingfor every religion. Besides, near the place for praying is also being built a wasp house as a symbol of hard work. Even this Wasp House surrounds the Bisbul tree where this tree is considered as a tree of harmony. It is because as a plant, the Bisbul tree has never been selective in giving oxygen to anyone. In other forms, the foundation also has a hall named Ir. Soekarno. The construction of the building with the name of the former president was a sign that this nation was championed by a community of various ethnic groups. The Indonesian nation must be one nation, in accordance with the symbol of the country, Bhineka Tunggal Ika.

Meanwhile, the process of transformation carried out by the teacher towards the students start from several main elements, which are by praying according to each religion and belief before starting learning or after the lesson is finished. Activities such as praying together are carried out by the teacher in order to create a harmonious atmosphere and also to introduce students to the value of tolerance in religious diversity. In addition, to hone the skills of the teachers, the foundation also creates training programs for teachers aimed at training professionalism in teaching the value of diversity.

To provide an understanding of democratic values in the learning process to the students, the foundation also provides understanding from the beginning of the students' admission. This can be seen from the election of the Student Council Chairperson, the Class Chairperson, the Chairperson of the Committee, and so on. As with the selection of the Student Council president, the students are allowed to do the campaign and debate before the election. This will be very beneficial for the students to instill the value of justice, freedom of opinion, and of course the value of democracy will berealized.

The foundation also often carries out cultural parties or Bhineka Tunggal Ikanight. In this activity, students from various ethnic groups will introduce their culture, both in art forms such as dances or in culinary forms. From theseactivities, the students will see that they come from various ethnicities and religions. Indirectly, they will realize that this diversity becomes 
a beauty that must be maintained. In addition, in providing learning the value of diversity in the classroom, the foundation also creates a multicultural curriculum through a lesson such asBahasa Indonesi lesson that discuss cookbook short stories, history teachers discuss material during the reform era, biology teachers discuss blood types, Civics teachers discuss tolerance behavior and harmony in diversity, mathematics teachers discuss bar charts, religious teachers discuss the value of affection, and teachers sociology discusses conflict material.

\section{Conclusion}

In this study, it was concluded that in Medan there was already a multicultural education process. As one of those which apply it theoretically and practically is the Yayasan Perguruan Sultan Iskandar Muda (YPSIM). This multicultural education aims to provide an understanding of diversity and the benefits of differences to foster a high tolerance for the students. This multicultural education is applied through two basic methods, through school culture and class culture. Through school culture means that the foundation makes several programs and policies related to multicultural values. Whereas through class culture, the foundation makes several policies in which teachers have a greater role in providing the understanding of diversity, which through their respective subject matter in the scope of the class.

\section{Reference}

Bank, J. A. 1981. Multicultural Education : Dimensions and Paradigms. Issues and perspectives. Boston-London : Allyn and Bacon Press.

Camilleri R. 2016. Global education and intercultural awareness in eTwinning, Teacher Education \& Development: Cogent Education. Taylor \& Francis Group DOI : 10.1080/2331186X.2016.1210489 3: 1210489, Vol Issue 1

Creswell W. J, 2014. Qualitative Inquiry \& Reserch Design, Choosing Among Five Appoaches, Third Edition, Sage ISBN,978-1-4129-9530-6

Carey, M.A. (1994). The group effect in focus groups: planning, implementing, and interpreting focus group research. In Critical Issues in Qualitative Research Methods (Morse J.M., ed.). Sage: Thousand Oaks, 225-241.

Dede Rosyad, 2014. Pendidikan multikultural di Indonesia sebuah pandangan konsepsional. Sosio Didaktika: Vol. 1, No. 1

Erlan Muliadi. 2012. Urgensi Pembelajaran Pendidikan Agama Islam Berbasis Multikultural di Sekolah. Jurnal Pendidikan Islam, DOI: 10.14421/jpi.2012.11.55-68, Volume I, No 1.

Gopinathan S. 2007. Globalisation, the Singapore developmental state and education policy: a thesis revisited, Globalisation, Societies and Education : Taylor \& Francis Group, DOI: 10.1080/14767720601133405 Vol. 5, No. 1

Grosfoguel Raul. 2004. Race and ethnicity or racialized ethnicities?, Thnicities : Sage Vol. 4 Iis Arifudin, 2007. Urgensi Implementasi Pendidikan Multikultural di Sekolah. Insania. Vol. 12. No. 2.

Ibnu Ambarudin, 2016. Pendidikan multikultural untuk membangun bangsa yang nasionalis religious. Jurnal Civics Vol. 13 No. 1.

Kolas Ashild, 2015. Framing the tribal: ethnic violence in Northeast India, Asian Ethnicity : Taylor \& Francis Group, DOI: 10.1080/14631369 .2015.1062050 ISSN : 1463-1369, Vol 18 , Issue 1 
Mahfud Choirul. 2006. Pendidikan Multikultural, Yogyakarta: Pustaka Pelajar

O'Connor Paul. 2017. Rhythmanalysis as a tool in social analysis on ethnicity in Hong Kong, Asian Ethnicity: Taylor \& Francis Group, DOI: 10.1080/14631369.2017.129211 8 ISSN: 1463-1369, Vol 19, Issue 1

Rozas \& Garran, 2013. Cultural Competence Revisited, Journal of Ethnic And Cultural Diversity in Social Work: Taylor \& Francis Group, DOI: 10.1080/15313204.2013.7853 37 22: 97-111, Vol 22. Issue 2

Venkatraman S. 2016. Cultural Statistics in Asia, Media Asia: Taylor \& Francis Group, DOI: 10.1080/01296612.2002.11726691 29:4 206-214.

Zainal Arifin, 2012. Pendidikan Multikultural-Religius untuk Mewujudkan Karakter Peserta Didik yang Humanis-Religius.Jurnal Pendidikan Islam, DOI: 10.14421/jpi.2011.11.89103, Volume I, No 1 